\title{
Cycle Rickshaw: History and Problems
}

\author{
Imma Widyawati Agustin \\ Urban Regional Planning Department \\ Brawijaya University \\ Malang, Indonesia \\ immasaitama@ub.ac.id
}

\begin{abstract}
Cycle rickshaw is one of the modes of paratransit transportation that has advantages in supporting the sustainability of the transportation system in Klojen District, Malang City. However, the provision of cycle rickshaw that is not in accordance to the needs of the community in Klojen District causes the community to feel less satisfied with the services provided. The main purpose of the study was to describe conditions, problems of cycle rickshaws and to determine the operational performance of cycle rickshaw in Klojen District, Malang City. The study used analysis of cycle rickshaw's operational performance, namely evaluative descriptive analysis by comparing each variable of operational performance with existing standards. The results showed that some of the operational performance of cycle rickshaw do not meet the existing standards with an average speed of 4.88 $\mathrm{km} / \mathrm{h}$, the average service distance of $1.25 \mathrm{~km}$, and the operational time of cycle rickshaw 7 to 9 hours per day.
\end{abstract}

Keywords: cycle rickshaw, paratransit, operational performance, Malang City

\section{INTRODUCTION}

Law Number 22 in 2009 concerning Road Traffic and Transportation guarantees the realization of public transportation services that are safe, secure, orderly, smooth and integrated for every color of the country that uses them. The law explains that in order to realize good service in the field of traffic and road transportation, every implementation of public transportation is obliged to provide services in accordance with established service standards. Passenger public transport is said to be good if its performance has been good and the main purpose of its existence has been achieved, namely to provide good and appropriate transportation services for the community [1].

The condition of public transport in urban areas in Indonesia at this time has not been well organized [2]. Public transport performance is inadequate, and service quality has not been a priority. Generally, the priority of the implementation of public transport at this time is to provide cheap public transportation so that it is affordable to all levels of society but often overrides service quality. The decline in the function of public transport services is one of the reasons because the public transportation does not have a good evaluation in terms of planning services in the future [3].

The PCE values of automatic rickshaws and rickshaws are very important for the analysis of the signal crossing capacity for mixed traffic conditions because this type of mode is very common and popular in several South Asian countries [4]. A predetermined fixed fee structure for tricycles is possible at the local or community level of the city, which might provide a way in the future for tariff integration [5]. Reference [6] presents data on accidents and real injuries among groups of motorized pedicab passengers and road users who were hit by motorized pedicabs. The main results included significant injury severity, and, importantly, the pattern of motorized pedicab passenger injuries comparable to pedestrians and two-wheeled vehicle users. Collisions with other vehicles are collision mechanisms that dominate and excess motorized tricycles and overthrowing also often occur. E-rickshaw have the potential to reduce fuel consumption for passenger transportation which can lead to economic and environmental benefits [7]. Other research attemps to report on a project whose purpose is to develop and compare various intelligent control strategies for optimal performance of fuel cell hybrid tricycles [8]. Reference [9] proves the importance of 'regulation' of urban space for the operation on informal transportation. In both cities, public urban space includes 'infrastructure' at various levels of formalization to enable informal transportation. The role of NMT modes such as cycle rickshaws, hand carts, animal carts, cycle rickshaws and head loads in five wholesale markets located in the walled city of Delhi [10]. each dealing with grain, textiles, parts, electricity and hardware in next to two wood wholesale markets and a fruit and vegetable market in Kotla, and Okhla in South Delhi.

Similar problems also occur in the type of cycle rickshaw transportation in Klojen Sub-District, Malang City. Provision of cycle rickshaw transport that is not in accordance with the needs of the community in Klojen Subdistrict causes the community to feel less satisfied with the services provided. Based on the survey results it is known that users of rickshaw transportation services have begun to decline by 50 percent. According to cycle rickshaw's drivers, the average number of passengers served at this time only ranges from 1-2 people a day, this decreases compared to the years before the emergence of motorized rickshaws and online transportation that can reach 3-5 passengers in a day. The decline in the number of cycle rickshaw's passengers is caused by several factors, one of which is due to the decline in the transportation of cycle rickshaw in Klojen District. This situation can be seen from the low level of service indicated by the low speed of cycle rickshaw transportation and expensive tariffs. Based on the results of interviews with cycle rickshaw's passengers, it is known that the speed of rickshaw transport which is slow to 
cause the travel time on average has a delay of 5-15 minutes longer compared to similar public transportation such as motorized rickshaws. In addition, the fees charged to cycle rickshaw's passengers can be more than 2 times more expensive (Primary Survey, 2019).

The impact of the decline in the performance of public transport which directly affects community satisfaction, has caused people to switch to other transportation that is more adequate [11]. Based on these matters, it is necessary to evaluate the operational performance of cycle rickshaws in Klojen District, Malang City.

\section{METHODS}

\section{A. Location}

The research "Cycle Rickshaw: History and Problems" was carried out in the Klojen Sub-district of Malang City which included 19 cycle rickshaws bases spread in Klojen Sub-district (Fig. 1).

\section{B. Population and Samples}

Sampling is divided into three, namely the driver, passenger and vehicle sample. In this study the determination of samples of drivers and cycle rickshaw's passengers used the Slovin formula to take the samples studied. The number of samples (n) is calculated using the Slovin formula as follows:

$$
n=\frac{\mathrm{N}}{1+\left(\mathrm{N} \times e^{2}\right)}
$$

Information:

$\mathrm{n}=$ number of samples needed

$\mathrm{N}=$ population

$\mathrm{e}=$ error rate (specified $5 \%)$

To find out the sample of rickshaw drivers, the population used is the number of rickshaws in Klojen subdistrict assuming that each rickshaw is driven by one person. While the population used to find out the samples of cycle rickshaw's passengers is the population in Klojen Subdistrict, Malang City. So that the sample calculation of rickshaw drivers and passengers is as follows:

\section{Driver's Sample:}

$$
n=\frac{353}{1+\left(353 \times 0.05^{2}\right)}=188 \text { drivers }
$$

Passenger's Sample:

$$
n=\frac{108637}{1+\left(108637 \times 0.05^{2}\right)}=398 \sim 400 \text { users }
$$

\section{Cycle Rickshaw's Sample:}

Sampling of rickshaws in this study used a minimum sample for descriptive research as according to [12] that is equal to $10 \%$ of the total population. The population used is the number of cycle rickshaw in Klojen Sub-district. So that the number of cycle rickshaw samples obtained is $10 \%$ of 353 cycle rickshaw units or 35 samples.

The results of calculating the driver, passenger and cycle rickshaw samples are then proportioned to each base.

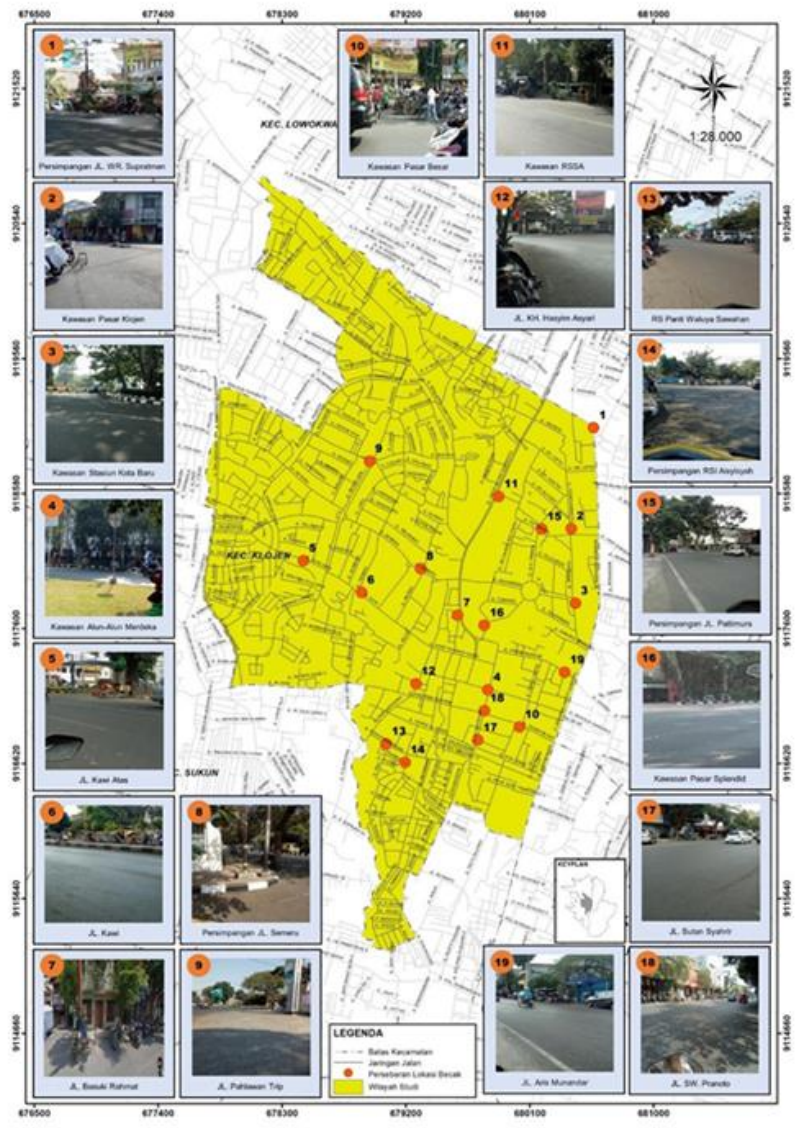

Fig. 1. Study Area Location.

\section{Operational Performance of Cycle Rickshaw}

The analytical method used in the analysis of cycle rickshaw operational performance is an evaluative descriptive analysis of average speed, average service distance, operating time, waiting time, travel rates, and how to get a cycle rickshaw to determine the characteristics of each performance variable described descriptively.

Furthermore, to find out whether the cycle rickshaw transport has been running well or not, it can be evaluated using the performance indicators of cycle rickshaw transport based on standards shown in TABLE I [13].

TABLE I. OPERATIONAL PERFoRMANCE PARAMETER OF CYClE RICKSHAW

\begin{tabular}{|l|l|l|}
\hline No. & \multicolumn{1}{|c|}{ Indicator } & \multicolumn{1}{c|}{ Parameter } \\
\hline 1 & Speed & $5 \mathrm{~km} / \mathrm{h}$ \\
\hline 2 & Distance & $1,75-2 \mathrm{~km}$ \\
\hline 3 & Operational time & $10-12 \mathrm{~h}$ \\
\hline 4 & Waiting time & $0-5$ minutes \\
\hline 5 & Cost & Based on the agreement \\
\hline 6 & $\begin{array}{l}\text { How to get the cycle } \\
\text { rickshaw }\end{array}$ & $\begin{array}{l}\text { Wait and be called on the } \\
\text { side of the road }\end{array}$ \\
\hline
\end{tabular}




\section{RESUltS AND DisCUSSION}

\section{A. Characteristic of Cycle Rickshaw in Malang City}

In general, the condition of rickshaws in Klojen Subdistrict, which are currently operating generally have not changed their appearance from the beginning until now. Fig. 2 shows the current condition of cycle rickshaw transport in Klojen Sub-district, Malang City.

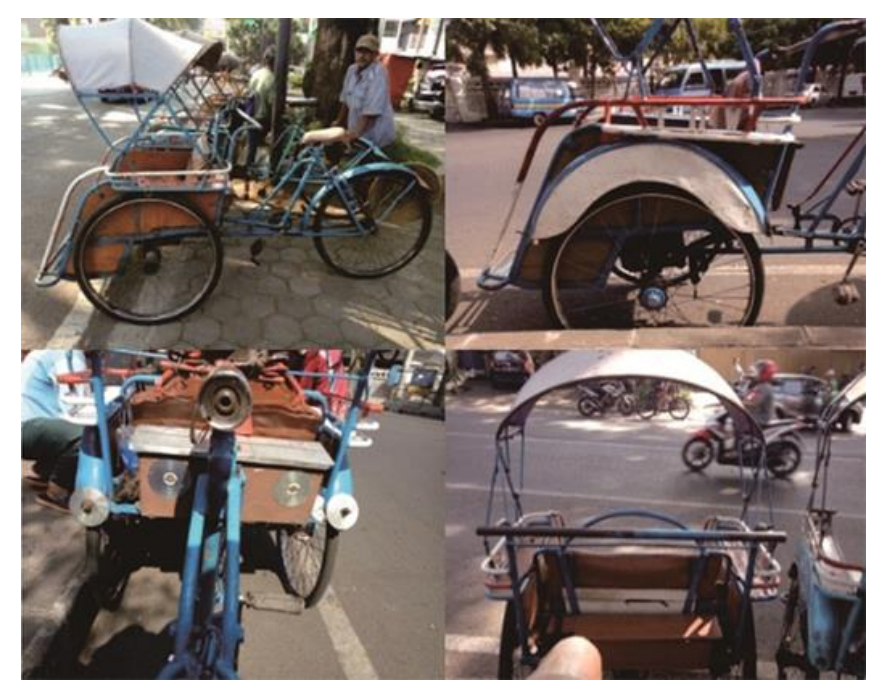

Fig. 2. Cycle Rickshaw Condition in Klojen Sub-district.

Cycle rickshaw transportation in Klojen Sub-district, Malang City uses three-wheeled vehicles in the form of bicycles and paddled using human power. There are two types of rickshaws based on the production series which are currently still used to operate in Klojen Sub-District, Malang City, namely Go Ah Pong (GAP) series rickshaw and series rickshaw output from Team Kim Wat (TKW). GAP's cycle rickshaw have dimensions of 2,100 mm long, 9 $00 \mathrm{~mm}$ wide and $1,450 \mathrm{~mm}$ high. While TKW's cycle rickshaw has dimensions of 2,200 $\mathrm{mm}$ in length, $900 \mathrm{~mm}$ in width and $1,550 \mathrm{~mm}$ in height.

All of cycle rickshaw transportation in Klojen Subdistrict, Malang City, all have suspension systems or shock absorbers located on the front wheels in the form of leaves which are installed between the wheel axle and the cycle rickshaw's body. In addition, the entire cycle rickshaw is also equipped with a brake system which is all in good condition. It's just that in terms of completeness of the fender, rickshaws in the District of Klojen Sub-district, Malang City are not all installed in the front wheel fender. On average cycle rickshaw that operate only have a fender on the back of a cycle rickshaw with a size of $300 \mathrm{~mm}$.

\section{B. Characteristic of Cycle Rickshaw Drivers}

The characteristics of the driver in the study were distinguished by age, education level, income level, ownership status of the cycle rickshaw and the participation of cycle rickshaw in the community. Recapitulation of characteristics of cycle rickshaw drivers in Klojen Subdistrict, Malang City shown in TABLE II.
TABLE II. CYCLE RICKSHAW'S DRIVER IN KLOJEN SUB-DISTRICT

\begin{tabular}{|c|c|c|c|}
\hline $\begin{array}{c}\text { Driver's } \\
\text { Characteristic }\end{array}$ & Sub-variable & Total & $\begin{array}{c}\text { Percentag } \\
\text { e }(\%)\end{array}$ \\
\hline \multirow{7}{*}{ Age } & $<20$ & 0 & 0 \\
\hline & $21-30$ & 0 & 0 \\
\hline & $31-40$ & 8 & 4 \\
\hline & $41-50$ & 30 & 16 \\
\hline & $51-60$ & 73 & 39 \\
\hline & $61-70$ & 51 & 27 \\
\hline & $>70$ & 26 & 14 \\
\hline \multirow{5}{*}{ Education } & No school & 17 & 9 \\
\hline & Elementary School & 147 & 78 \\
\hline & Junior High School & 15 & 8 \\
\hline & Senior High School & 9 & 5 \\
\hline & $\mathrm{D} 3 / \mathrm{S} 1 / \mathrm{S} 2$ & 0 & 0 \\
\hline \multirow{5}{*}{ Income } & $0-500,000$ IDR & 122 & 65 \\
\hline & $500.000-1.000 .000 \mathrm{IDR}$ & 32 & 17 \\
\hline & 1.000.000-1.500.000 IDR & 23 & 12 \\
\hline & $1.500 .000-2.000 .000$ IDR & 8 & 4 \\
\hline & $>2.000 .000 \mathrm{IDR}$ & 3 & 2 \\
\hline \multirow{2}{*}{$\begin{array}{l}\text { Cycle Rickshaw } \\
\text { Ownership } \\
\text { Status }\end{array}$} & Private & 126 & 67 \\
\hline & Rent & 62 & 33 \\
\hline \multirow{2}{*}{$\begin{array}{l}\text { Participation of } \\
\text { The Rickshaw's } \\
\text { Community }\end{array}$} & Join in & 0 & 0 \\
\hline & Not joined & 188 & 100 \\
\hline
\end{tabular}

Age Level

Cycle Rickshaw drivers are dominated by the age range of 51-60 years. This shows that most Cycle Rickshaw drivers have gone through the profession as Cycle Rickshaw drivers for a long time.

\section{Education Level}

The majority of Cycle Rickshaw drivers are elementary school graduates. The data shows that the majority of Cycle Rickshaw drivers in Klojen Sub-district come from low education backgrounds.

\section{Income Level}

The majority of the income of the Cycle Rickshaw driver is 0 to $500,000.00$ per month. The data shows that the income of Cycle Rickshaw drivers in Klojen Sub-district in one month is still relatively low.

\section{Cycle Rickshaw Ownership Status}

The average ownership status of cycle rickshaw in Klojen Sub-district is privately owned with a percentage of $67 \%$ and rent of $33 \%$.

\section{Participation of the Cycle Rickshaw Community}

$100 \%$ of Cycle Rickshaw drivers in Klojen Sub-district do not join an association.

\section{Passenger Characteristic of Cycle Rickshaw}

The characteristics of Cycle Rickshaw passengers in Klojen Sub-district are distinguished by gender, age, type of work, income level, and travel destination can be seen in TABLE III. 
TABLE III. PASSENGER CHARACTERISTIC OF CYCLE RICKSHAW

\begin{tabular}{|c|c|c|c|}
\hline $\begin{array}{c}\text { Passenger } \\
\text { Characteristic }\end{array}$ & Sub-Variable & Total & $\begin{array}{c}\text { Percentage } \\
(\%)\end{array}$ \\
\hline \multirow{2}{*}{ Gender } & Male & 40 & 10 \\
\hline & Female & 360 & 90 \\
\hline \multirow{9}{*}{ Age (years old) } & $0-15$ & 8 & 2 \\
\hline & $16-20$ & 40 & 10 \\
\hline & $21-25$ & 40 & 10 \\
\hline & $26-30$ & 52 & 13 \\
\hline & $31-35$ & 28 & 7 \\
\hline & $36-40$ & 52 & 13 \\
\hline & $41-45$ & 52 & 13 \\
\hline & $46-50$ & 84 & 21 \\
\hline & $>50$ & 52 & 13 \\
\hline \multirow{4}{*}{ Education Level } & Elementary School & 28 & 7 \\
\hline & Junior High School & 80 & 20 \\
\hline & Senior High School & 216 & 54 \\
\hline & $\mathrm{D} 3 / \mathrm{S} 1 / \mathrm{S} 2$ & 76 & 19 \\
\hline \multirow{8}{*}{ Occupation } & Student & 12 & 3 \\
\hline & College Student & 24 & 6 \\
\hline & Civil Servant & 52 & 13 \\
\hline & Teacher & 12 & 3 \\
\hline & Private & 68 & 17 \\
\hline & Entrepreneur & 52 & 13 \\
\hline & Retired & 4 & 1 \\
\hline & Housewife & 176 & 44 \\
\hline \multirow{5}{*}{ Travel Destination } & Market & 120 & 30 \\
\hline & Home & 172 & 43 \\
\hline & School & 24 & 6 \\
\hline & $\begin{array}{l}\text { Public } \\
\text { Transportation }\end{array}$ & 16 & 4 \\
\hline & Others & 68 & 17 \\
\hline
\end{tabular}

Gender

The majority of cycle rickshaw passenger in Klojen Subdistrict are female because of the need for transportation modes with a high level of privacy to prevent the danger of crime.

\section{Age Level}

Cycle Rickshaw passenger in Klojen Sub-district are dominated by people aged 46 to 50 years old. The physical limitation factor has caused elderly people to prefer to use a cycle rickshaw because of the service that can deliver passengers to the door (door to door).

\section{Education Level}

The majority of the education level of cycle rickshaw passengers in Klojen Sub-district, Malang City is high school or vocational school which is equal to $54 \%$ then followed by respondents with junior high school level which is equal to $20 \%$ of respondents with a high school or vocational education background of $19 \%$ and elementary school respondents $7 \%$.

\section{Occupation (Jobs)}

The largest number of cycle rickshaw passenger jobs is housewives. Passengers with this type of work as housewives tend to use cycle rickshaw to go to the market and vice versa.

\section{Travel Destination}

The type of trip that is the destination of passengers by using a cycle rickshaw is dominated by trips to homes, markets and other public places (others).

\section{Operational Performance of Cycle Rickshaw}

TABlE IV. Distance and TRAVEl Time of CyCle Rickshaw

\begin{tabular}{|c|c|c|c|}
\hline Base Origin & Destination & $\begin{array}{c}\text { Distance } \\
(\mathbf{k m})\end{array}$ & $\begin{array}{c}\text { Travel } \\
\text { time } \\
\text { (minutes) }\end{array}$ \\
\hline $\begin{array}{l}\text { W.R Supratman } \\
\text { Crossroads }\end{array}$ & Bunul Market & 1.2 & 15 \\
\hline Klojen Market & Narotama Street & 1.1 & 13 \\
\hline Baru City Station & Merdeka Square & 1.1 & 14 \\
\hline \multirow{4}{*}{$\begin{array}{l}\text { Alun-Alun } \\
\text { Kecamatan Klojen }\end{array}$} & Besar Market & 0.75 & 9 \\
\hline & $\begin{array}{l}\text { Malang Olympic } \\
\text { Gardent }\end{array}$ & 1.2 & 13 \\
\hline & Besar Market & 0.75 & 10 \\
\hline & Bs Riyadi Street & 1.7 & 21 \\
\hline Kawi Atas Street & Mergan Market & 1.2 & 14 \\
\hline \multirow{2}{*}{ Kawi Street } & Simpang Gading Street & 1.7 & 22 \\
\hline & Besar Market & 1.6 & 20 \\
\hline $\begin{array}{l}\text { Basuki Rahmat } \\
\text { Street }\end{array}$ & Baru City Station & 1.1 & 14 \\
\hline Semeru Crossroads & Oro-Oro Dowo Market & 1.1 & 13 \\
\hline \multirow{16}{*}{ Besar Street } & Kebalen Wetan Street & 1.3 & 15 \\
\hline & Ir Rais Street & 1.8 & 22 \\
\hline & $\begin{array}{l}\text { Malang Olympic } \\
\text { Garden }\end{array}$ & 1.7 & 22 \\
\hline & Ramayana & 0.65 & 8 \\
\hline & Seleyer Street & 0.95 & 12 \\
\hline & Gadang Gg 4 & 2.9 & 35 \\
\hline & Brawijaya Street & 1.4 & 17 \\
\hline & Muharto Gg 8 & 1.5 & 18 \\
\hline & Ngaglik Gg 4 & 1.5 & 19 \\
\hline & Polehan Gg Mawar & 1.7 & 22 \\
\hline & Janti Selatan & 2.7 & 32 \\
\hline & Andalas Tengah Street & 1.5 & 18 \\
\hline & Comboran Market & 0.9 & 11 \\
\hline & Halmahera Street & 1.3 & 16 \\
\hline & $\begin{array}{l}\text { Mergosono Butake Gg } \\
3 \mathrm{~b}\end{array}$ & 1.8 & 22 \\
\hline & Merdeka Barat Street & 0.75 & 9 \\
\hline $\begin{array}{l}\text { Saiful Anwar } \\
\text { Hospital }\end{array}$ & Lai-lai Fruit Store & 1.5 & 19 \\
\hline $\begin{array}{l}\text { KH Hasyim Ashari } \\
\text { Street }\end{array}$ & Kawi Street & 0.85 & 11 \\
\hline $\begin{array}{l}\text { Aisyiyah Moslem } \\
\text { Hospital } \\
\text { Intersection }\end{array}$ & Wiro Margo & 0.8 & 10 \\
\hline $\begin{array}{l}\text { Sutan Syahrir } \\
\text { Street }\end{array}$ & Besar Market & 0.4 & 6 \\
\hline S.W Pranoto Street & Besar Market & 0.4 & 5 \\
\hline $\begin{array}{l}\text { Aris Munandar } \\
\text { Street }\end{array}$ & Baru City Station & 1 & 12 \\
\hline \multicolumn{2}{|l|}{ Total } & 43.8 & 539 \\
\hline \multicolumn{2}{|l|}{ Average } & 1.25 & 15.4 \\
\hline
\end{tabular}

\section{Speed}

The average speed of travel using cycle rickshaw transportation in this study was carried out by calculating the travel distance data divided by travel time. Data on 
hours a day and more than 15 hours a day are 39\%,

distance and travel time of cycle rickshaw in Klojen Subdistrict can be seen in TABLE IV.

The results of calculating the average speed value of rickshaws in Klojen Sub-district are as follows:

$$
V=S / T
$$

$V=1.25 \mathrm{~km} /[(15.4 / 60)$ hour $]$

$V=4.88 \mathrm{~km}$ per hour

The average speed of cycle rickshaw services in Klojen Sub-district, Malang City is $4.88 \mathrm{~km}$ per hour. The data shows that the average speed of cycle rickshaw in Klojen Sub-district is still below the standard calculation of the existing average speed, which is an average of $5 \mathrm{~km}$ per hour or can be said to be a little slower. The less optimal average speed of cycle rickshaw in Klojen Sub-district, Malang City, is influenced by the age of the driver, most of whom are elderly.

\section{Service Distance}

The average service distance of rickshaw transportation in Klojen Subdistrict, Malang City based on the calculation of the data in TABLE IV is as follows:

$S=V x T$

$S=4.88 \mathrm{~km} /$ hour x $[(15.4 / 60)$ hour $]$

$S=1.25 \mathrm{~km}$

The distance of this service when compared to the existing standard is smaller than 1.5 to $1.75 \mathrm{~km}$. The data shows that the operational performance of cycle rickshaw in terms of average service distance is still below the ideal standard. The average distance of the cycle rickshaw service in Klojen Sub-district influences the amount of tariff charged to cycle rickshaw users because the farther the distance between the cycle rickshaw's services, the higher the fare obtained by cycle rickshaw drivers shown in TABLE V.

TABLE V. TRAVEL COST OF CYCLE RICKSHAW

\begin{tabular}{|l|l|l|}
\hline \multicolumn{1}{|c|}{ Distance $\mathbf{( k m )}$} & \multicolumn{1}{|c|}{ Minimal Cost } & \multicolumn{1}{|c|}{ Maximal Cost } \\
\hline $0-1$ & $5.000 \mathrm{IDR}$ & $10.000 \mathrm{IDR}$ \\
\hline $1-2$ & $10.000 \mathrm{IDR}$ & $15.000 \mathrm{IDR}$ \\
\hline $2-3$ & $15.000 \mathrm{IDR}$ & $20.000 \mathrm{IDR}$ \\
\hline $3-4$ & $20.000 \mathrm{IDR}$ & $25.000 \mathrm{IDR}$ \\
\hline $4-5$ & $25.000 \mathrm{IDR}$ & $30.000 \mathrm{IDR}$ \\
\hline
\end{tabular}

\section{Operational Time}

The operational time in question is the length of time used by cycle rickshaw drivers in getting passengers. The length of operation is calculated starting from the driver leaving the house until returning home again.

Based on Fig. 3, it is known that as many as $29 \%$ of cycle rickshaw drivers operate on average for 7 hours to 9 hours in one day. Furthermore, as many as $11 \%$ of cycle rickshaw drivers operate for 10 hours to 12 hours a day. Then $8 \%$ of cycle rickshaw drivers operate less than 10 respectively. The data shows that as many as $54 \%$ of cycle rickshaw in Klojen Sub-district, Malang City, operate below the existing standard. This mismatch causes the operational performance of cycle rickshaw to decrease because it cannot meet passenger demand. The operational time of cycle rickshaw in Klojen Sub-district has an effect on the number of passengers that can be served by cycle rickshaw. The survey results show that the longer the rickshaw operates, the number of passengers obtained by cycle rickshaw drivers will also increase.

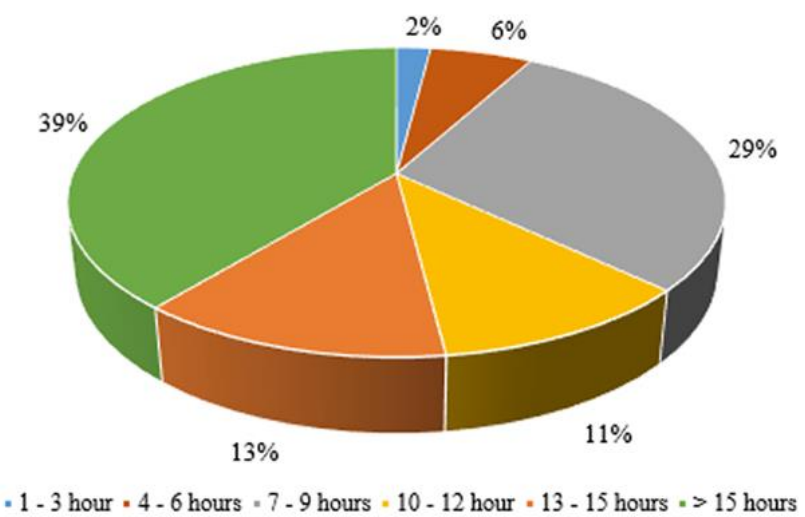

Fig. 3. Duration of Operational Time of the Cycle Rickshaw.

\section{Waiting Time}

The waiting time referred to in this study is the time required by prospective passengers to get cycle rickshaw. The waiting time depends on the way the passenger gets the cycle rickshaw and the distance between the passenger location and the cycle rickshaw base.

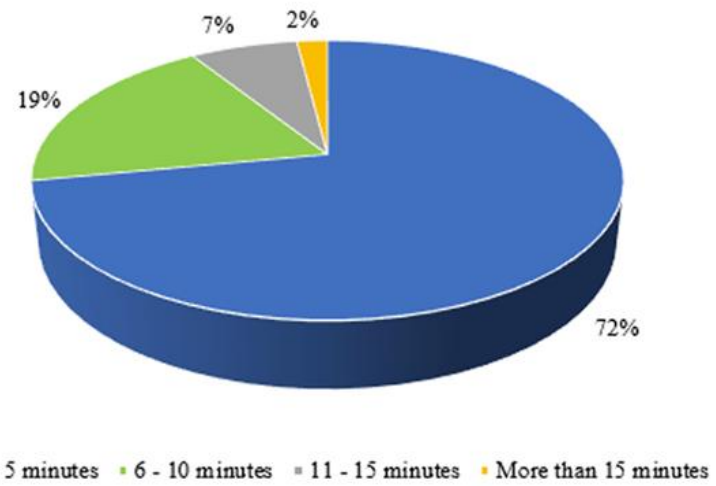

Fig. 4. Waiting Time of the Cycle Rickshaw.

Fig. 4 shows that the waiting time for passengers to get rickshaws is almost less than 10 minutes with details of $72 \%$ of passengers having a waiting time of 0 to 5 minutes, then as many as $19 \%$ of passengers waiting for rickshaw for 6 minutes to 10 minutes and as many as $7 \%$ of passengers waiting for cycle rickshaw during 11 minutes to 15 minutes and for passengers who have to wait more than 15 minutes which is as much as $2 \%$. The average passenger who waits for 0 to 5 minutes is looking for cycle rickshaw by going to the base because based on the characteristics of the cycle rickshaw base location in Klojen Sub-district, the average is in the area which is the center of activity and located on the 
highway. This shows that the waiting time for rickshaw transport is in the ideal time range.

\section{Travel Cost}

Determination of cycle rickshaw cost in Klojen Sub-district, Malang City is based on a mutual agreement between the driver and the passenger of the rickshaw. The size of the tariff charged to passengers varies depending on the size of the distance traveled shown in TABLE V

Based on TABLE V, it is shown that the average amount charged for one trip with a distance of $0-5 \mathrm{~km}$ is starting from 5,000.00 to 30,000.00 IDR. The tariff will continue to increase as the distance traveled by cycle rickshaw passengers increases. This shows that the fare for rickshaw transportation is in accordance with the existing provisions, namely based on mutual agreement. However, in determining the amount of travel tariffs, the minimum tariff standard from the government has not yet been established, so that the public perception of the fare of travel using cycle rickshaw varies. Thus, there needs to be a directive in determining the minimum tariff for cycle rickshaw by the local government so as not to harm one party both the driver and the cycle rickshaw passenger.

\section{How to Get a Cycle Rickshaw}

The location of the cycle rickshaw base in Klojen Subdistrict, Malang City is widely spread around the public facilities, highway sections to the crossroads can be found cycle rickshaw base. This certainly makes it easier for people in Klojen Sub-district to get rickshaws.

As many as $79 \%$ of prospective cycle rickshaw passengers get cycle rickshaw by going to the base or calling to the base. This is usually done by prospective passengers whose activity location is close to the cycle rickshaw base. How to subscribe is usually done by passengers who commute round trip at certain hours such as going to the market and school which is equal to $11 \%$. Whereas the way to get cycle rickshaw by waiting and calling on the roadside is now rarely done, which is only $8 \%$ because it requires a longer time to wait for the rickshaw to pass without passengers.

In addition to the method above, to get a cycle rickshaw is also done by booking via telephone or short message. Passengers who get cycle rickshaw in this way have only reached $2 \%$. This method was chosen by a small part of the community because there were no cycle rickshaw bases around the place of prospective passengers and even if there was a long distance. So that people choose to order cycle rickshaw via telephone or short message.

\section{CONCLUSIONS}

Travel behaviour research in Indonesia has been done on The operational performance of cycle rickshaw shows that there are still several aspects of operational performance that have not met existing service standards, among others, the average service distance of cycle rickshaw by $1.25 \mathrm{~km}$, the average speed of cycle rickshaw by $4.88 \mathrm{~km}$ per hour, and the operational time of cycle rickshaw only for 7 hours to 9 hours per day.

\section{REFERENCES}

[1] Government of Republic of Indonesia, Law No.22 On Traffic and Road Transport, 2009.

[2] Warpani, P. Suwardjoko, Planning the Transportation System (in Indonesian). Bandung: ITB publisher, 1990.

[3] Haryono, Sigit. Analysis of the Quality of Public Transport Services (City Bus) in Yogyakarta (in Indonesian). Business Administration Journal, Vol. 07 No.01, Page 1-14, 2010.

[4] Md. Mizanur Rahman, Izumi Okura, Fumihiko Nakamura, Effects of Rickshaws and Auto-Rickshaws on the Capacity of Urban Signalized Intersections. IATSS Research Vol.28 No.1, 2004.

[5] M. Shafiq-Ur Rahman, Paul Timms, Francis Montgomery, Integrating BRT Systems with Rickshaws in Developing Cities to Promote Energy Efficient Travel. Procedia - Social and Behavioral Sciences 54,2012 , pp. $261-274$.

[6] Uli Schmucker, Rakhi Dandona, G. Anil Kumar, Lalit Dandona, Crashes involving motorised rickshaws in urban India: Characteristics and injury patterns. Injury, Int. J. Care Injured 42, 2011, pp. 104-111.

[7] Deepanjan Majumdar, Tushar Jash. Merits and Challenges of ERickshaw as An Alternative form of Public Road Transport System: A Case Study in the State of West Bengal in India. Energy Procedia 79, 2015, pp. $307-314$.

[8] Mohammed Abu Mallouh, Lindsay McInnes, Brian Surgenor, Brant Peppley, Intelligent Control for Optimal Performance of a Fuel Cell Hybrid Auto Rickshaw. Energy Procedia 29, 2012, pp. 367 - 376.

[9] Dirk Heinrichs, Mirco Goletz, Barbara Lenz, Negotiating territory: strategies of informal transport operators to access public space in urban Africa and Latin America. Transportation Research Procedia 25, 2017, pp. 4507-4517.

[10] Sanjay Gupta, Role of Non-Motorized Transport in Distribution of Goods in the Metropolitan City of Delhi. Transportation Research Procedia 25, 2017, pp. 978-984.

[11] Puspitasari, Devi, Analysis of Rural Public Transportation Service Needs based on Respondent's Perceptions (Case Study : Nanggulan District, Kulon Progo Regency) (in Indonesian). Final Exam. Yogyakarta: Gajah Mada University, 2017.

[12] Saputra, Indra, Performance Analysis of Rural Public Transportation Services in Bangko - Jangkat Route (in Indonesian). Final Exam. Bandung: Pasundan University, 2016.

[13] Arianty, S W. Evaluation and Operational Performance Costs of the Bondowoso Rickshaw (in Indonesian). Final Exam. Malang: Brawijaya University, 2008. 